\title{
CAIMAN CF. LATIROSTRIS (ALLIGATORIDAE, CAIMANINAE) IN THE LATE MIOCENE PALO PINTADO FORMATION, SALTA PROVINCE, ARGENTINA: PALEOGEOGRAPHIC AND PALEOENVIRONMENTAL CONSIDERATIONS
}

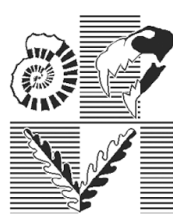

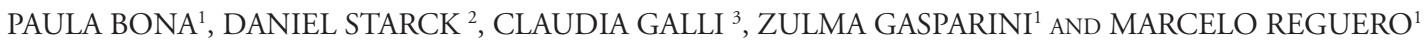

${ }^{1}$ División Paleontología Vertebrados, Museo de La Plata, Paseo del Bosque s/ n, B1900FWA La Plata, Argentina - Consejo Nacional de Investigaciones Científicas y Técnicas.pbona@fcnym.unlp.edu.ar; zgaspari@fcnym.unlp.edu.ar; regui@fcnym.unlp.edu.ar

${ }^{2}$ Tecpetrol S.A. daniel.starck@tecpetrol.com; daniel@starck.im

${ }^{3}$ Facultad de Ingeniería, Universidad Nacional de Jujuy - Facultad de Ciencias Naturales, Universidad Nacional de Salta, Argentina. claudiagalli@fibertel.com.ar

\begin{abstract}
The three recognized species of Caiman-C. latirostris, C. yacare and C. crocodilus- currently live in northern and central South America. Except for the fragmentary dentary of a putative Caiman from Oligocene rocks in Brazil, the genus has been reliably recorded in rocks of ages spanning the Neogene, when species of Caiman were a constant component of the South American crocodyliofauna. The major taxonomical diversification of Caiman occurred during the late Miocene, which is well documented in the area of Paraná (northeastern Argentina). Fossil crocodylians in Paraná are represented by one gavialid and caimanines, with at least five species of Caiman (including C. latirostris). This assemblage represents the southernmost record of Crocodylia living in "Amazonia" during the Miocene. In this work we confirm the record of Miocene caimans outside the Paraná and we prove the presence of Caiman cf. latirostris in present-day northwestern Argentina during the late Miocene. The taxonomic identification is based on a fragment of a left mandible with the same ornamentation, outline and dentition as Caiman, and with a symphyseal morphology similar to that of Caiman latirostris. The material comes from the upper part of the Palo Pintado Formation in the southern region of Valle Calchaquí (Salta Province). This unit was deposited in a sand-gravel fluvial system with associated ponds between $10.29 \pm 0.11 \mathrm{Ma}(\mathrm{K} / \mathrm{Ar})$ and $5.27 \pm 0.28 \mathrm{Ma}\left({ }^{206} \mathrm{~Pb} /{ }^{238} \mathrm{U}\right)$.
\end{abstract}

Key words . Crocodylia. Caiman. Neogene. Salta Province. Argentina.

Resumen. CAIMAN CF. LATIROSTRIS (ALLIGATORIDAE, CAIMANINAE) EN LA FORMACIÓN PALO PINTADO DEL MIOCENO TARDÍO, PROVINCIA DE SALTA, ARGENTINA: CONSIDERACIONES PALEOGEOGRÁFICAS Y PALEOAMBIENTALES. El género Caiman está actualmente representado por tres especies, C. latirostris, C. yacare y C. crocodilus, distribuidas en el norte-centro de América del Sur. Exceptuando un resto fragmentario de dentario de un probable Caiman proveniente de rocas oligocenas de Brasil, este género se registra con seguridad desde el Mioceno y sus especies constituyeron un componente constante de la crocodilofauna sudamericana durante el Neógeno. La mayor diversificación taxonómica de Caiman ocurrió durante el Mioceno tardío y se encuentra bien documentada en el área de Paraná (noreste de Argentina). Los cocodrilos fósiles allí registrados son una especie de gavial y caimaninos, representados por al menos cinco especies de Caiman (incluyendo C. latirostris). Esta asociación constituye el registro más austral de Crocodylia que habitaron la "Amazonia" durante el Mioceno. En este trabajo se confirma el registro de caimanes fuera del área de Paraná y se demuestra la presencia de Caiman cf. latirostris en el Mioceno tardío en el noroeste de Argentina. La determinación taxonómica se basa en un fragmento izquierdo de mandíbula, con la misma ornamentación, contorno y dentición que en Caiman, y con una morfología de la región sinfiseal similar a la que presenta C. latirostris. El material proviene de niveles superiores de la Formación Palo Pintado en el área sur de los Valles Calchaquíes (Provincia de Salta). Esta unidad fue depositada en un ambiente fluvial areno-gravoso con lagunas asociadas y pantanos entre los $10.29 \pm 0.11 \mathrm{Ma}$ $(\mathrm{K} / \mathrm{Ar})$ y los $5.27 \pm 0.28 \mathrm{Ma}\left({ }^{206} \mathrm{~Pb} /{ }^{238} \mathrm{U}\right)$.

Palabras clave. Crocodylia. Caiman. Neógeno. Provincia de Salta. Argentina.

THE so called "modern caimans" include the living representatives of Caimaninae, which is a monophyletic group of mainly South American Alligatoridae (Brochu, 1999, 2011). Six species of caimanines are currently recognized: Caiman crocodilus (Linnaeus, 1758), Caiman yacare (Daudin, 1802) (occasionally considered a subspecies of $C$. crocodilus), Caiman latirostris (Daudin,1802), Melanosuchus niger (Spix, 1825),
Paleosuchus palpebrosus (Cuvier, 1807) and Paleosuchus trigonatus (Cuvier, 1807). Although the monophyly of this group is widely supported by morphological and molecular evidence (Densmore and Owen, 1989; Norell, 1988; Brochu, 1999, 2003; Gatesy et al., 2003; Aguilera et al., 2006; Hrbek et al., 2007; Willis et al., 2007; Willis, 2009), the systematics of the genus Caiman Spix, 1825, is controversial (Norell, 1988; 
Poe, 1997; Brochu, 1999). The most accepted hypothesis divides the lineage in three species (C. latirostris, C. yacare and C. crocodilus; Busack and Pandya, 2001, see also Crocodile Specialist Group's web site http://www.iucncsg.org/pages/Publications.html and cites herein), mainly distributed in centraleastern South America. Except for Caiman tremembensis Chiappe, 1988 -a putative member of the genus described on the basis of material from Oligocene rocks in southastern Brazil (Tremembé Formation; São Paulo State) and which needs to be revised in the light of modern knowledge- Caiman has been recorded only since the early Miocene (Langston, 1965) in South America. Its species have been consistent components of the South American crocodyliofauna during the Neogene.

During the Miocene, the evolutionary history of Crocodylia (sensu Benton and Clark, 1988) in South America was characterized by large morphological and taxic diversification of lineages such as Alligatoridae (Brochu, 2003; Riff et al., 2010; Bona et al., in press). Alligatorid genera show a wide geographic distribution (Mourasuchus Price, 1946; Purussaurus Barbosa-Rodrigues, 1892; Caiman) and local species-level endemism (Bona et al., in press). This situation is particularly documented and studied in the north of the continent (e.g., La Venta, Colombia; Urumaco, Venezuela; Acre, Brazil). However, in southern areas of Amazonia (sensu Hoorn et al., 2010), the most abundant and best studied record of crocodylians is that of northeastern Argentina (NEA; Bravard, 1858; Burmeister, 1883; Ambrosetti, 1887; Scalabrini, 1887; Rovereto, 1912; Rusconi, 1933, 1935; Langston, 1965; Gasparini, 1973; Langston and Gasparini, 1997; Cione et al., 2000, Bona et al., 2013, in press). The taxonomic diversity recorded in this area includes one gavialoid (Gryposuchus neogaeus Burmeister) and at least five Caiman species (including C. latirostris; Bona et al., in press).

Conversely, the Miocene crocodylian record in other Argentine localities is sparse and always fragmentary. Starck and Vergani (1996) and Starck and Anzótegui (2001) reported a mandibular fragment tentatively referred to Caiman sp. found in the Palo Pintado Formation in the Calchaquí Valley, Salta Province (Fig. 1). Such a generic determination, although correct, was not supported by a comparative morphological study. This record from outside the Paraná area broadens the southern geographic distribution of late Miocene caimanines. Knowledge of the caimanine fossil record during the Neogene at these latitudes is essential not only to understand the evolutionary and biogeographic history of Caiman, but also to provide an empirical basis for the interpretation of the evolution of natural environments in northern Argentina. This enhances the significance of this material -collected with precise stratigraphic control- enough to justify its study.

This work is based not only on a detailed anatomical comparative analysis of this fossil material of Caiman (Fig. 2), but also on sedimentological and paleontological observations of the exposures of the Palo Pintado Formation in the Quebrada de Salta (Fig. 3). Hence, one of the goals of this study is a paleoenvironmental interpretation based on the architectural-element level and the bounding-surface hierarchy and its relationship with the fossil crocodile specimen which, subsequently, suggest a possible scenario in which this caimanine may have lived.

\section{GEOLOGICAL AND CHRONOSTRATIGRAPHIC SETTING}

The studied material was collected from upper beds of the Palo Pintado Formation (Mauri, 1948; Díaz and Malizzia, 1983) exposed in the Quebrada de Salta in the southern Calchaqui Valley (between $25^{\circ} 41^{\prime} 34^{\prime \prime} \mathrm{S}-66^{\circ} 03^{\prime} 31^{\prime \prime} \mathrm{W}$ and $25^{\circ} 37^{\prime} 17^{\prime \prime} \mathrm{S}-66^{\circ} 03^{\prime} 26^{\prime \prime} \mathrm{W}$; Fig. 1). This unit is part of the Payogastilla Group (Díaz and Malizzia, 1983), which comprises (from base to top) the Los Colorados, Angastaco, Palo Pintado and San Felipe formations. The measured thickness of this group exceeds $6 \mathrm{~km}$ in the area and was deposited in a Cenozoic (middle Eocene-Pliocene) foreland basin related to the Andean Orogeny (Starck and Vergani, 1996). Part of this foreland basin developed over the previous Salta Group Rift Basin (Cretaceous-Paleogene).

The Palo Pintado Formation comprises fluvial system deposits that are well exposed in the outcrops at Quebrada de Salta. Lithofacies boundaries and the characteristics and geometries of the architectural elements are documented in the stratigraphic column (Fig. 1) and in the photo mosaic of the outcrop (Fig. 3). The principles on bounding surface hierarchies of Miall (1985, 1994, 1995 and 2006) were followed for architectural analysis, with minor modifications to adapt these principles to the studied deposits. Lithofacies descriptions and their interpretation are summarized in Appendix 1 (Supplementary Online Information).

The Palo Pintado Formation was deposited between 10 
Ma (K/Ar) (Galli et al., 2008) and 5.2 Ma (Coutand et al., supported conglomerates, clean quartzitic and sublithic sand2006; Bywater Reyes et al., 2010) and is mainly composed of stones and is topped by green shale levels. These cycles have upward fining and thinning cycles. Each cycle involves matrix been interpreted as the record of rivers intermediate between

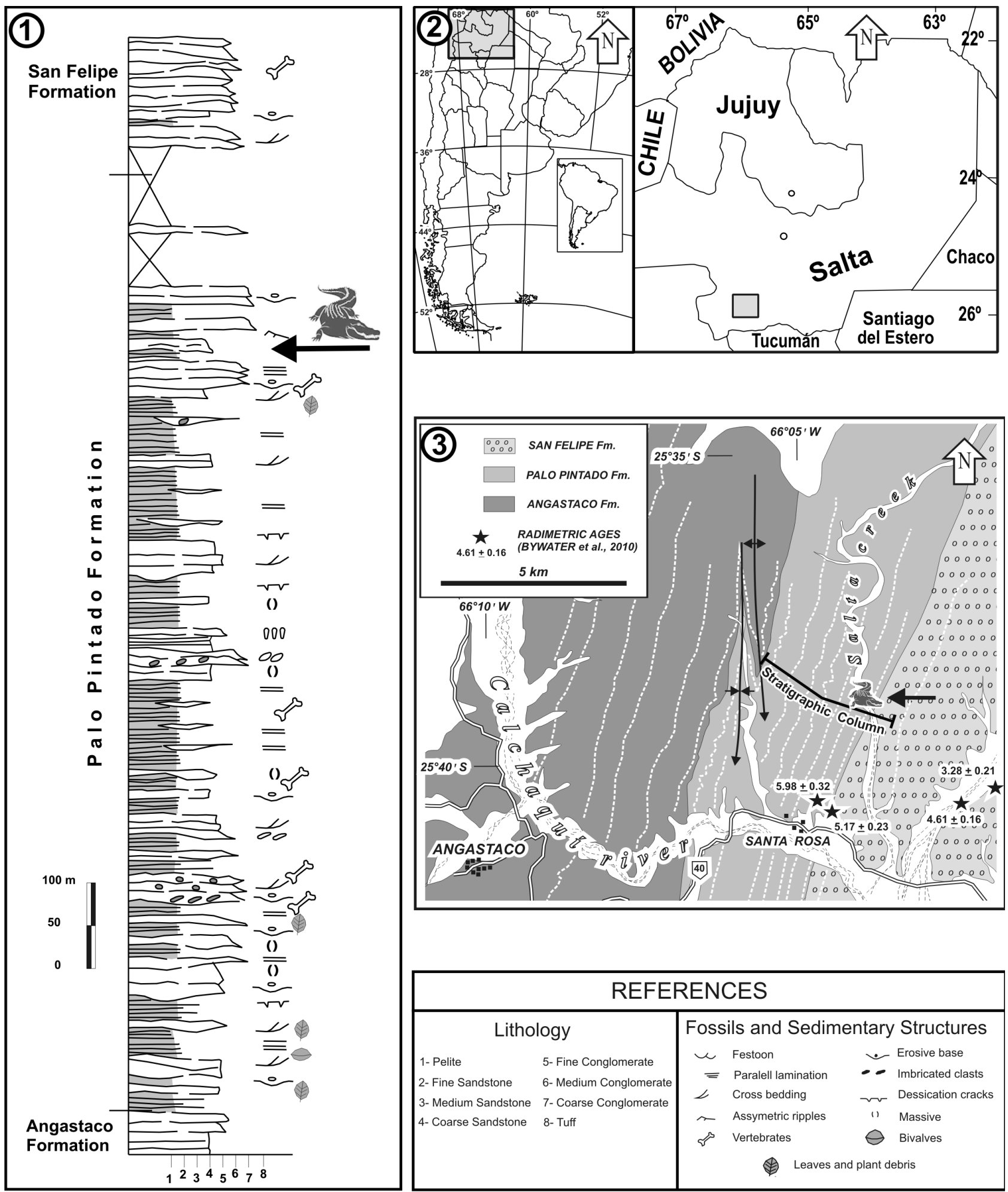

Figure 1. 1. Palo Pintado stratigraphic column at the Quebrada Salta section (location in 1.3) with the fossil stratigraphic location. 2. Geographic location of the study area (southern Calchaqui valley). 3. Geological map of the study area with the stratigraphic column and fossil location. Radimetric ages (Tuff zircons U-Pb) in Ma. 
low sinuosity, multichannel rivers and others with highly sinuous and simple channels in a sandy-gravel wandering fluvial system (Galli et al., 2011a).

The Palo Pintado Formation measured $1100 \mathrm{~m}$ at the surveyed section. The unit overlies transitionally the coarser Angastaco Formation and grades upward into the San Felipe Formation (fluvial and alluvial). The Palo Pintado and San Felipe formations form a continuous coarsening- and thickening-upward megasequence several kilometers thick (Starck and

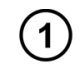

(2)

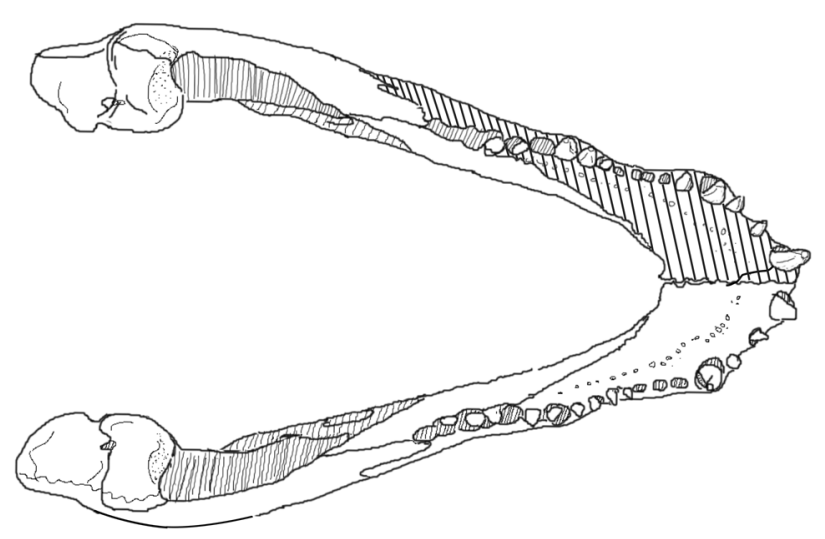

(3)

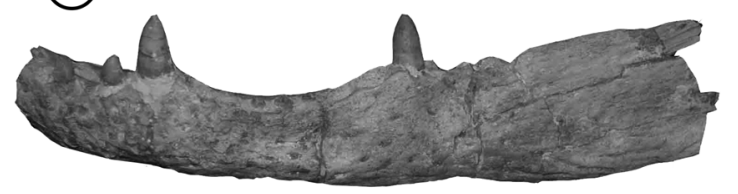

(4)

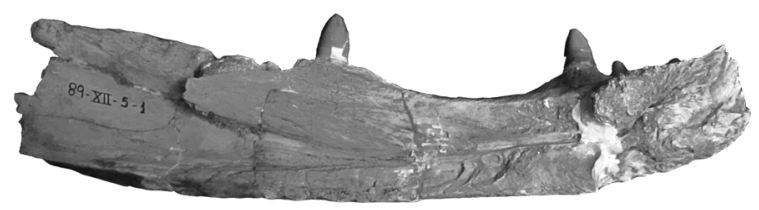

Figure 2. 1, 3, 4, Caiman cf. latirostris, MLP 89-XII-5-1; 1, dorsal view; 3, lateral view; 4, medial view. 2, C. latirostris, extant specimen, mandible in dorsal view. Scale bar $=10 \mathrm{~cm}$.
Vergani, 1996).

The lower and middle sections of the Palo Pintado Formation contain a highly diverse fossil assemblage: well-preserved leaves (Herbst et al., 1987; Anzótegui, 1998, 2006), fructifications (Anzótegui et al., 2007), logs (Lutz and Martínez, 2007), palynomorphs (Anzótegui and Cuadrado, 1996; Acevedo et al., 1997; Mautino, 2007), bivalves (Morton, 1992; Herbst et al., 2000) and vertebrates (Díaz et al., 1987, 1989; Starck and Vergani, 1996; Starck and Anzótegui, 2001).

\section{MATERIALS AND METHODS}

For the comparative study of specimen MLP 89-XII-5-1, a sample of 149 modern alligatorid specimens from herpetological collections was studied. The material is housed in the Museo de La Plata, La Plata, Argentina (MLP); Museo Argentino de Ciencias Naturales "Bernardino Rivadavia”, Buenos Aires, Argentina (MACN) and Zoologische Staatssammlung, Munich, Germany (ZSM). The sample included 25 specimens of C. latirostris, 74 of C. yacare, three of P. trigonatus (Schneider), five of $P$. palpebrosus Cuvier, 30 of Melanosuchus niger, one of Alligator sinensis Fauvel and one of A. mississippiensis. Additional specimens of Miocene caimans used as comparative material were those figured by Langston (1965), Brochu (1999), Medina (1976), Sánchez Villagra and Aguilera (2006), Gasparini (1981) and also specimens under study (Bona et al., 2013, in press) housed in the MLP and MACN.

\section{SYSTEMATIC PALEONTOLOGY}

Crocodylia Gmelin, 1789 sensu Benton and Clark, 1988

Alligatoridae Cuvier, 1807 sensu Norell et al., 1994

CAimAninae Brochu, 2003 (according to Norell, 1988)

\section{Caiman Spix, 1825}

Type species. Caiman fissipes Spix, 1825; original designation, central and southern South America, Recent.

\section{Caiman cf. Iatirostris (Daudin, 1802)}

Figure 2

Additional material. MLP 89-XII-5-1, fragment of left mandibular ramus, with most of the dentary, teeth $4^{\text {th }}$ and $12^{\text {th }}$ complete and implanted, and fragments of the $6^{\text {th }}$ through $9^{\text {th }}$ teeth (Fig. 2.1, 3, 4).

Geographic and stratigraphic provenance. Quebrada Salta, southern area of the Calchaquí Valley: 2539'04"S$66^{\circ} 04^{\prime} 00^{\prime \prime} \mathrm{W}$, Salta Province. Upper levels of the Palo Pintado Formation (Díaz and Malizzia, 1983); late Miocene (Fig. 1). 

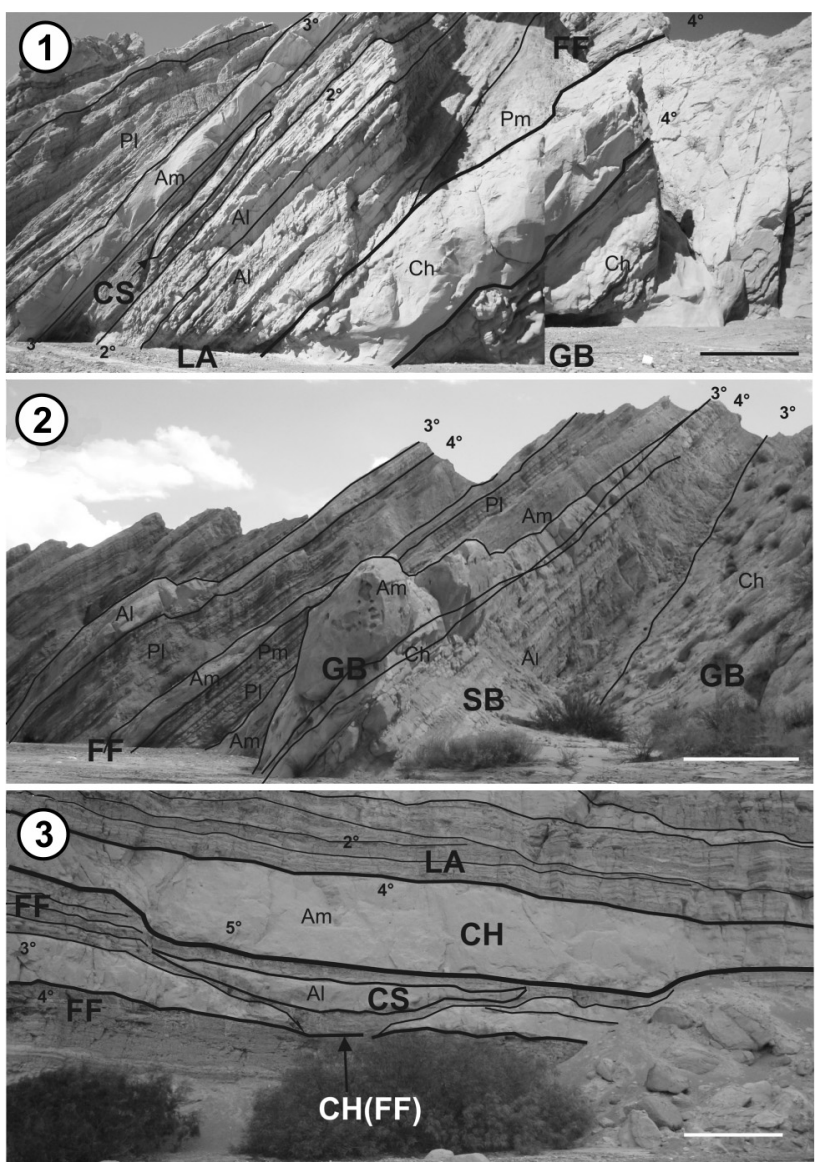

Figure 3. 1, Channel-fill deposits are dominated by lithofacies $\mathrm{Ch}$ with sand lithofacies Am forming the upper part of the bar deposits, with fining-upward successions (GB) and the arquitectural-element with lateral -accretion (LA), scale bar $=2 \mathrm{~m}$. 2, Facies showing a sequence of channel facies (GB) and floodplain fines with crevasse chanel (FF), scale bar $=2 \mathrm{~m}$ ). 3, abandoned channel fills (element FF-CH-), scale bar $=4 \mathrm{~m}$.

\section{Description}

Dentary. Except for a small posterior fragment, the dentary is complete. It is similar in morphology to other specimens of Caiman with well marked curves of the dorsal margin (in lateral view) between the alveoli 1 and 4-12 (Fig. 2.3,4). Hence, as in the other adult caimans (e.g., C. latirostris, C. yacare, $C$. crocodilus), the dimensional heterodonty is marked: the largest dentary teeth are the $1^{\text {st }}, 4^{\text {th }}, 11^{\text {th }}$ and $12^{\text {th }}$. These are implanted at the highest points of this bone. Alveoli 1 and 4 are high, at the same level, and as in other caimanines the anterior part of the dentary (at the level of alveolus 4 ) is as high as the middle part (at the level of alveolus 12). As in other caimans, the ornamentation of the lateral surface is given by small holes grouped on the symphyseal and latero-dorsal region, and continues with thin dichotomized furrows extended mainly over the ventral surface of the bone.
In dorsal view (Fig. 2.1) the mandibular symphysis extends posteriorly at the level of the posterior margin of alveolus 5 and forms a straight angle with the medial margin of the dentary. The latter curves posterolaterally at alveolus 6 forming a $135^{\circ}-157^{\circ}$ angle with the symphysis.

This adult specimen is similar in size and robustness to large specimens of extant C. latirostris (i.e., MACN V 1420, Bona and Desojo, 2001; Fig. 2). The dentary is $22 \mathrm{~cm}$ long from the anterior end of the bone to the posterior margin of the last alveolus. The proportions of the mandibular symphysis area are $6.7 \mathrm{~cm}$ length and width (measured on the sagittal axis of the specimen and at a $90^{\circ}$ angle with the mandibular symphysis).

Splenial. This bone is not preserved, but the scar of its contact with the dentary is exposed in medial view (Fig. 2.4). It was excluded from the mandibular symphysis and it extended anteriorly through a projection dorsal to the Meckelian furrow. This condition is common to all Caimaninae and a synapomorphy of the clade (Brochu, 1999).

Dentition. Eighteen dentary alveoli are preserved in MLP 89XII-5-1. The last four are partially preserved because of the lack of splenial, which in complete specimens bounds the medial part of the last alveoli. However, it can be inferred that these converge as in other caimans. The alveolar pattern of labiolingual diameter and space between alveoli is similar to that of Caiman: the width of the first alveolus, partially preserved, is similar to that of alveolus 4; alveoli 2 and 3 are small and well spaced, from 5 to 9 they decrease in size and then they increase from 10 to 12 .

The best preserved teeth $(\mathrm{d} 2, \mathrm{~d} 3, \mathrm{~d} 4, \mathrm{~d} 12)$ are similar in morphology to those of other caimans. They are conical, with smooth vertical striae and an anteroposterior carina dividing the tooth into two sub-equal surfaces, "labial" or lateral, and lingual or medial.

\section{Comparisons}

In MLP 89-XII-5-1 the anterior projection of the splenial is dorsal to the Meckelian furrow as in members of Caimaninae. Unlike Eocaiman Simpson, and the large caimanines such as Mourasuchus Price and Purussaurus Barbosa Rodriguez, it has two marked wavelets in lateral view; hence, alveoli 1, 4 and 12 are almost at the same height. Unlike Paleosuchus Gray, the alveoli are not compressed laterally. In MLP 89-XII-5-1 the ornamentation of the lateral surface of the dentary and the 
alveolar pattern are similar to those of Melanosuchus Spix and Caiman. As in these genera, the symphysis extends up to the posterior margin of alveolus 5 (in C. latirostris the length of the symphysis varies among species reaching up to the 5 or $5-$ 6 alveoli; Bona and Desojo, 2011). Both the angle between the symphysis and the medial margin of the dentary, and the outline of the lower mandible show that the dentary is from an animal with a broad snout, similar to C. latirostris (Fig. 2.12). As mentioned above, in MLP-89-XII-5-1 the medial margin (inner) of the dentary in dorsal view is straight in relation to the symphysis and then it curves postero-laterally forming an angle of approximately $157^{\circ}$. This condition is different from that in other species of living caimans such as Caiman yacare and Melanosuchus niger, in which the internal margin of the dentary is postero-laterally oriented without curving, forming an angle of approximately $170^{\circ}$ with the mandibular symphysis.

\section{DISCUSSION}

Caiman has not been adequately defined from an osteological point of view. According to phylogenetic hypotheses based on morphological data (Brochu, 1999, 2011; Bona et al., 2013, in press), Caiman and Melanosuchus form a clade supported by the presence of prominent rostral crests on the snout, by the morphology of the fronto-parietal suture, and by the arrangement of scales on the ventral side of the neck (Brochu, 1999). Nevertheless, molecular analyses generally support monophyly of Caiman exclusive of Melanosuchus.

In a phylogenetic analysis of the taxa represented in the Miocene of Paraná, Bona et al. (2013, in press) proposed that the relative size of the temporal fenestrae and the orbits, and the pattern of the alveoli and premaxillary-maxillary diastema (and possibly its counterpart in the dentary), could be potentially diagnostic characters of Caiman. In this context, these authors proposed the synonymy of Melanosuchus and Caiman (Norell, 1988; Poe, 1997). Caiman would have differentiated at least in the middle Miocene of South America (Bona and Paulina Carabajal, 2013), being the late Miocene the time of greatest morphological and taxonomical diversification. This diversification includes the differentiation of the mordern species of this genus (e.g., Caiman latirostris and probably C. yacare, Bona et al., 2013, in press), the oldest record of which is documented in the area of Paraná, in levels assigned to the late Miocene ("Conglomerado osífero"; Cione et al., 2000; Brandoni and Scillato-Yané, 2007; Brandoni, 2011).

Detailed morphological study of specimen MLP 89-XII-51 allows its assignment to the Caimaninae Caiman, and the similar outline of the symphyseal region allows considering it as Caiman cf. latirostris (Fig. 2.1,2). The record of Caiman cf. latirostris, now verified for the Miocene of northwestern Argentina, demonstrates a wider distribution of this taxon during this times interval.

As mentioned above, specimen MLP 89-XII-5-1 was collected from the upper Palo Pintado Formation, close to its transition into the overlying San Felipe Formation. Both units yielded $\mathrm{U}-\mathrm{Pb}$ zircon ages from their abundant intercalated piroclastic levels (Coutand et al., 2006; Bywater Reyes et al., 2010). One of these available ages (5.98 $\pm 0.32 \mathrm{Ma}$; Bywater Reyes et al., 2010) came from a level slightly lower than the Caiman bearing bed; thus the specimen should be slightly younger than 6 ma.

\section{Paleonvironmental and paleogeographic considerations}

According to the architectural element characteristics of the Palo Pintado Formation and its associated lithofacies, this unit represents a fluvial system with deposits developed in both channels and overbanks. The intrachannel record is composed of gravel bars (GB) and bedform deposits related to downstream migration and vertical accretion of transverse bars and sand waves (SB). On the other side, the overbank deposits are represented by lateral accretion bars (LA) on the floodplain, small channels carved in the main channel edges during flooding stages interpreted as crevasse channels (CS), and a floodplain (FF) (Fig. 3).

The overall architectural-element characteristics are akin to a sinuous gravel fluvial system with intermediate to high sinuosity (Gravel-bed wandering river; Miall, 1985).

Compared to the Miall's model (Miall, 1985), the Palo Pintado Formation deposits show a dominance of the SB element. Based on this fact, a sandy-gravel wandering fluvial system denomination has been proposed for them (Galli et al., 2011a).

Sedimentologic analysis and fossil content suggest relatively humid climate during deposition of the Palo Pintado Formation. Preliminary X-ray diffraction data from floodplain clay minerals revealed the presence of illite, montmorillonite, magnesium-rich smectite and caolinite generated by hydroly- 
(2)

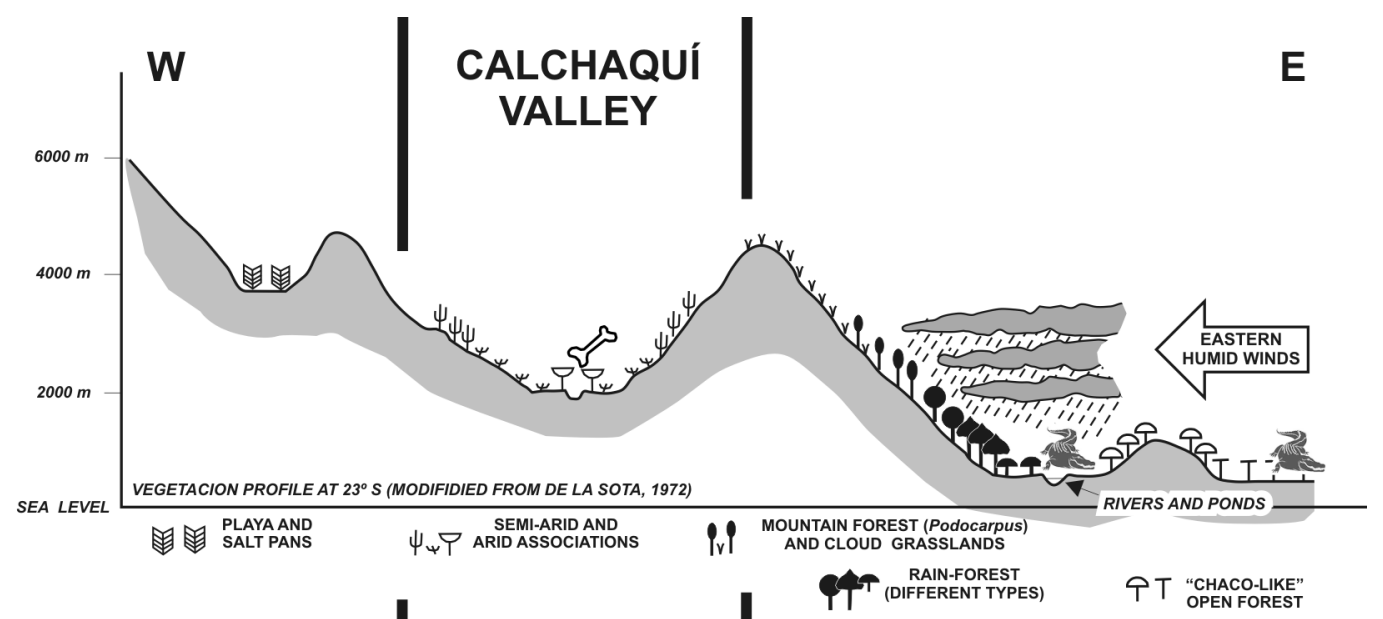

(1)

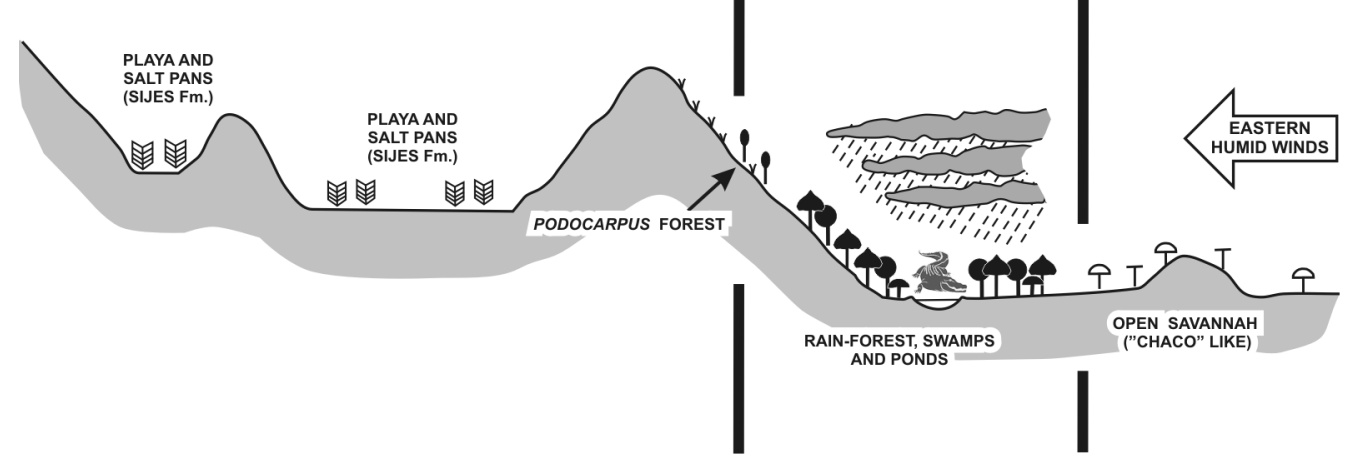

Figure 4. Schematic topographic profiles showing the paleoenvironment distribution (modified from Starck and Anzótegui, 2001). 1. Situation at $6 \mathrm{Ma}$ (deposition time for the upper section of the Palo Pintado Fm). 2. Present day situation.

sis under a warm and humid climate (Galli et al., 2011a,b). The formation of these clay minerals during the deposition of the Palo Pintado Formation is another evidence of benign climatic conditions, compared with the mostly arid ones previous to $10 \mathrm{Ma}$ (during the deposition of the Angastaco Formation, Starck and Vergani, 1996; Starck and Anzótegui, 2001).

In this paleoenvironmental scenario, the studied fossil was found in cross- laminated sandstone beds (At) representing the transverse bedforms setting (SB). The occurrence of Caiman cf. latirostris also supports the hypothesis that the climatic conditions in Valle Calchaquí during the late Miocene were comparatively more benign than those inferred for contemporaneous units deposited to the east (Guanaco Formation, Orán Group).

From a more regional perspective, the Palo Pintado Formation was deposited at the front of a contemporaneous orogenic belt in an overall setting similar to the present-day Chaco Plains, specially their western sectors close to the Andean foothills (Starck and Vergani, 1996; Starck and Anzótegui,
2001). Paleoenvironment dynamics in northwestern Argentina during the late Neogene was strongly controlled by the advance of the Andean Orogen front. The eastward thrust belt propagation pushed in the same direction the humid environments developed at the bottom of the foothills (Fig. 4). To the west, behind the orogenic front, intermontane valleys were coevally originated. These were higher and under dryer climatic conditions (e.g., the present-day Valle Calchaquí). Thus, during the last $6 \mathrm{Ma}$ (since the late Miocene), the orogenic front propagated approximately $150 \mathrm{~km}$ to the east (at a rate of about $2.5 \mathrm{~cm} /$ year) pushing the related climatic belts. The distribution of Caiman cf. latirostris seems to accompany that displacement; thus, the current geographic distribution of the species can be explained in terms of a retraction process related to climatic changes controlled by orogenic causes.

Caiman latirostris is currently found in Paraguay, southern and eastern Brazil, much of Bolivia (“Amazonas Boliviano") and northern and northeastern Argentina. In Argentina, this species extends further south than other species of the genus (Larriera and Imhof, 2000) and has been recorded in the 


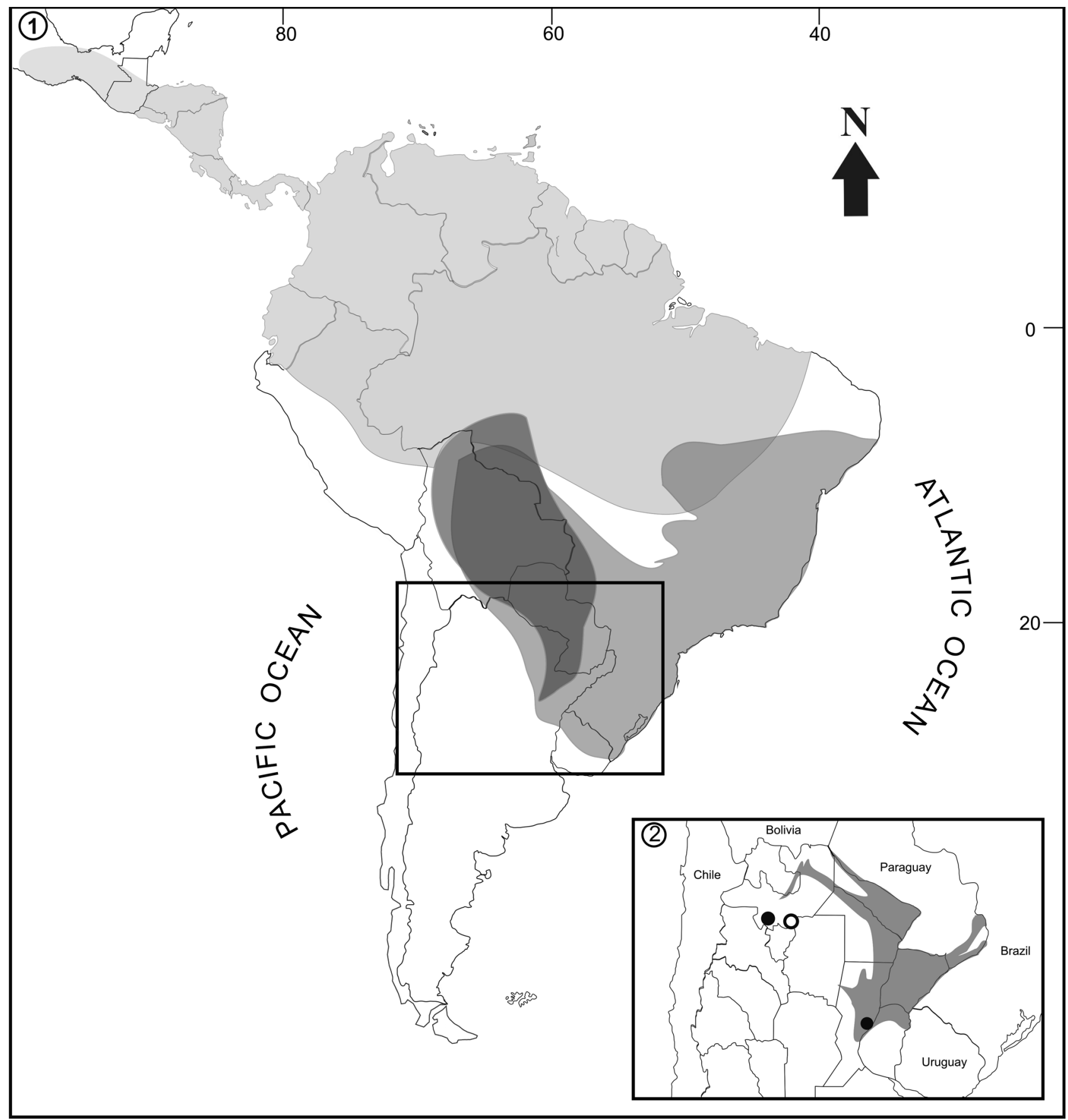

Figure 5. 1. Geographic distribution of Caiman genus in South America; the three areas in gray, from light gray to dark gray, indicate the present distribution of C. crocodilus, C. latirostris and C. yacare, (respectively) 2. Detail of geographic distribution of Caiman latirostris in Argentina; gray area indicates the present distribution of the species; black circles indicate the distribution of Caiman cf. latirostris in the upper Miocene (left) and white circle indicates the distribution of $C$. latirostris in the Pliocene.

provinces of Chaco, Corrientes, Formosa, Santa Fe, Entre Ríos, Misiones, Salta and Jujuy (Fig. 5). In Salta Province, living populations of Caiman latirostris are restricted to the northeast (basins of the Bermejo and Pilcomayo rivers). It inhabits environments with abundant vegetation and lentic water bodies such as the pantanal and floodplains of rivers and creeks developed under a subtropical to warm-temperate and humid climate (Fig. 3; Freiberg and Carvalho, 1965; Cei, 1993 Piña et al., 2004; Rueda-Almonacid et al., 2007; Barrios, 2013). These environmental and climatic conditions were those probably existing between 10 and $5 \mathrm{Ma}$ in the Valle Calchaquí. 


\section{CONCLUSIONS}

This study confirms the occurrence of Caiman cf. latirostris in the late Miocene in northwestern Argentina. It also extends the paleogeographic distribution of the genus and explains the presence of this taxon in younger rocks in eastern locations within Salta Province (e.g., Rosario de la Frontera, Plioceneearly Pleistocene and Aguas Blancas, Pleistocene; Paterson, 1936; Barrios, 2013). Thus, the idea that the biogeographic history of Caiman in the area was a story of expansion and (mainly) retraction clearly appears (in view of the environmental and climatic changes occurred during the late Neogene) linked to tectonic events (see Starck and Anzótegui, 2001).

Sedimentological and facial analyses carried out in the area (Quebrada Salta) suggest a preliminary hypothesis on the Palo Pintado Formation depositional subenvironments (Supplementary Online Information: Appendices 1 and 2). For the time- interval analyzed, the basin infill was deposited by an intermediate-sinuosity, sand-gravel wandering fluvial system. The sinuosity reflects low regional topographic gradients. Other outstanding characteristics of the studied sequences are the abundance of At lithofacies, several channel styles often associated to swamps and the development of grey paleosoils, all indicatives of fluvial systems developed under tropical climates (Miall, 2006). These climatic conditions lasted in the Valle Calchaquí area until at least 5 Ma, allowing the development of a varied flora and fauna, including the studied Caiman cf. latirostris.

\section{AKNOWLEDGEMENTS}

We thank A. Kramarz, S. Alvarez (MACN, Paleontología Vertebrados); S. Nenda (MACN, Herpetología); E.P. Tonni (MLP, Paleontología Vertebrados), and L. Alcalde (MLP, Herpetología) for access to materials under their care; $\mathrm{J}$. Desojo for the photographs of materials for comparison, and M. Tomeo for the illustrations and design of figures. This study was partially funded by Agencia Nacional de Promoción Científica y Tecnológica (PICT 2008-0261), CONICET (PIP 2010-2012 N² 298) and CI-UNSa Nº 1858.

\section{REFERENCES}

Acevedo, T.L., Mautino, R.L., Anzótegui, L.M. and Cuadrado, G.A. 1997. Estudio palinológico de la Formación Palo Pintado (Mioceno superior), Provincia de Salta, Argentina. Parte II: Esporas. Geociencias 2: 112-120.

Aguilera, O.A, Riff, D. and Boquentin-Villanueva, J. 2006. A new giant Purussaurus (Crocodyliformes, Alligatoridae) from the Upper Miocene Urumaco Formation, Venezuela. Journal of Systematic Palaeontology 4: 221-232.

Ambrosetti, J.B. 1887. Observaciones sobre los reptiles fósiles Oligocenos de los terrenos Terciarios del Paraná. Boletín de la Academia Nacional de Ciencias de Córdoba 4: 409-426.

Anzótegui, L.M. 1998. Hojas de angiospermas de la Formación Palo Pintado, Mioceno superior, Salta, Argentina. Parte I: Anacardiaceae, Lauraceae y Moraceae. Ameghiniana 35: 25-32.
Anzótegui, L.M. 2006. [Paleofloras del Mioceno en los Valles Calchaquies, Noroeste de Argentina: Corrientes, Argentina. Ph.D. dissertation, Universidad Nacional del Nordeste, Corrientes; 266 p. Unpublished].

Anzótegui, L.M. and Cuadrado, G.A. 1996. Palinología de la Formación Palo Pintado, Mioceno superior, Provincia de Salta, República Argentina. Parte I: Taxones nuevos. Revista Española de Micropaleontología 28: 77-92.

Anzótegui, L.M., Horn, M.Y., Mautino, L.R. and Garralla, S.S. 2007. Diversificación de Cyperaceae en los Valles Calchaquíes durante el Mioceno Medio-Plioceno, $31^{\circ}$ Jornadas Argentinas de Botánica (Corrientes). Boletín de la Asociación Argentina de Botánica 42 (Suplemento): 117.

Barbosa-Rodrigues, B. 1892. Les Reptiles fossiles de la vallée de l'Amazone. Vellosia 2: 41-46.

Barrios, F. 2013. Presencia de Caiman latirostris (Daudin, 1802) (Crocodylia, Alligatoridae) en la Formación Piquete (Plioceno-Pleistoceno temprano) de la provincia de Salta, Argentina: implicancias paleoambientales y sistemáticas. Ameghiniana 50: 522-534.

Benton, M.J. and Clark, J.M. 1988. Archosaur phylogeny and the relationships of the Crocodylia. In: M.J. Benton (Ed.), The phylogeny and classification of the tetrapods. Clarendon Press, Oxford, p. 295-338.

Bona, P. and Desojo, J.B. 2011. Osteology and Cranial Musculature of Caiman latirostris (Crocodylia: Alligatoridae). Journal of Morphology. DOI: $10.1002 /$ jmor.10894.

Bona, P. and Paulina Carabajal, A. 2013. Caiman gasparinae sp. nov., a huge alligatorid (Caimaninae) from the late Miocene of Paraná, Argentina. Alcheringa: An Australasian Journal of Palaeontology. DOI:10.1080/03115518.2013.785335

Bona, P., Riff, D and Gasparini, Z. 2013. Late Miocene crocodylians from Northeast Argentina: new approaches about the austral components of the Neogene South American crocodylian fauna. Earth and Environmental Science Transactions of the Royal Society of Edinburgh 103: 1-20.

Bona, P., Riff, D. and Gasparini, Z. In press. Los Alligatoridae del Mioceno Superior de Argentina: el registro más austral de cocodrilos neógenos en América del Sur. In: J. Noriega and D. Brandoni (Eds.), El Neógeno de la Mesopotamia Argentina. Asociación Paleontológica Argentina, Publicación Especial.

Bravard, A. 1858. Monografía de los terrenos marinos terciarios del Paraná. Diario oficial del Gobierno: El Nacional Argentino. Reimpreso por Burmeister, G. 1883.

Brandoni, D. 2011. The Megalonychidae (Xenarthra, Tardigrada) from the late Miocene of Entre Ríos Province, Argentina, with remarks on their systematics and biogeography. Geobios 44: 33-44.

Brandoni, D. and Scillato-Yané, G.J. 2007. Los Megatheriinae (Xenarthra, Tardigrada) del Terciario de Entre Ríos, Argentina: aspectos taxonómicos y sistemáticos. Ameghiniana 44: 427-434.

Brochu, C.A. 1999. Phylogenetics, Taxonomy and Historical Biogeography of Alligatoroidea. In: T. Rowe, C.A. Brochu and K. Kishi (Eds.), Cranial Morphology of Alligator mississippiensis and Phylogeny of Alligatoroidea. Memoir of the Journal of Vertebrate Paleontology 6: 9-100.

Brochu, C.A. 2003. Phylogenetic approaches toward crocodylian history. Annual Review of Earth and Planetary Sciences 31: 357-396.

Brochu, C.A. 2011. Phylogenetic relationships of Necrosuchus ionensis Simpson 1937 and the early history of caimanines. Zoological Journal of the Linnean Society 163: 228-256.

Burmeister, G. 1883. Reprint of Bravard, 1858: Monografía de los terrenos marinos terciarios del Paraná. Annales del Museo Público de Buenos Aires 3: 45-94.

Busack, S.D. and Pandya, S. 2001. Geographic variation in Caiman crocodilus and Caiman yacare (Crocodylia: Alligatoridae): systematic and legal implications. Herpetologica 57: 294-312.

Bywater-Reyes S., Carrapa B., Clementz M. and Schoenbohm L. 2010. Effect of late Cenozoic aridification on sedimentation in the Eastern Cordillera of northwest Argentina (Angastaco basin). Geology 38: 235-238.

Cei, J.M. 1993. Reptiles del noroeste, nordeste y este de la Argentina. Museo Regionales di Historia Naturali di Torino, Monografie 14: 1-949.

Chiappe, L.M. 1988. Un nuevo Caiman (Crocodylia, Alligatoridae) de la Formación Tremembé (Oligoceno), Estado de Sao Paulo, Brasil, y su significado paleoclimático. Paula-Coutiana 3: 49-66.

Cione, A.L., Azpelicueta, M.M., Bond, M., Carlini, A., Casciotta, J., Coz- 
zuol, M.A., de la Fuente, M., Gasparini, Z., Goin, F., Noriega, J., ScillatoYané, G., Soibelzon, L., Tonni, E., Verzi, D. and Vucetich, M.G. 2000. Miocene vertebrates from Entre Ríos province, Argentina. Serie Correlación Geológica 14: 191-238.

Coutand, I., Carrapa, B., Deeken, A., Schmitt, A.K., Sobel, E. and Strecker, M.R. 2006. Orogenic plateau formation and lateral growth of compressional basins and ranges: Insights from sandstone petrography and detrital apatite fission-track thermochronology in the Angastaco Basin, NW Argentina. Basin Research 18: 1-26.

Cuvier, G.L. 1807. Sur les differentes especes de crocodiles vivans et sur leur caracteres distinctifs. Annales du Muséum National d'Histoire Naturelle 10: 8-66.

Daudin, F.M. 1802. Histoire naturelle, générale et particulière des Reptiles. F. Dufart, Paris, 452 p.

De la Sota, E.R. 1972. Sinopsis de las Pteridofitas del Noroeste de Argentina, I. Darwiniana 17: 16- 50 .

Densmore, L.D. and Owen, R.D. 1989. Molecular systematics of the Order Crocodilia. American Zoologist 29: 831-841.

Díaz, J.I. and Malizzia D. 1983. Estudio geológico y sedimentológico del Terciario Superior del Valle Calchaquí (Dpto. San Carlos, Pcia. de Salta). Facultad de Ciencias Naturales, Universidad Nacional de Tucumán, Boletín Sedimentológico, 2: 8-28.

Díaz, J.I., Malizzia, D. and Bossi, G. 1987. Análisis estratigráfico del Grupo Payogastilla, $10^{\circ}$ Congreso Geológico Argentino (San Miguel de Tucumán), Actas 2: 113-116.

Díaz, J.I., Miserendino Fuentes, A. and Esteban, G. 1989. Edad y fósiles del Grupo Payogastilla, Valle Calchaquí - Salta, Argentina. $8^{\circ}$ Congreso Geológico de Bolivia, Actas 1: 309-326.

Freiberg, M.A and Carvalho, A.L. 1965. El yacaré sudamericano Caiman latirostris (Daudin). Physis 25: 351-360.

Galli, C.I., Ramírez, A., Barrientos, C., Reynolds, J., Viramonte, J.G. and Idleman, B. 2008. Estudio de proveniencia de los depósitos del Grupo Payogastilla (Mioceno Medio-Superior) aflorantes en el río Calchaquí, provincia de Salta, Argentina, $17^{\circ}$ Congreso Geológico Argentino, Actas 1: 353-354.

Galli C.I., Anzótegui, L.M., Horn, M.Y. and Morton L.S. 2011a. Paleoambiente y paleocomunidades de la Formación Palo Pintado (MiocenoPlioceno), provincia de Salta, Argentina. Revista Mexicana de Ciencias Geológicas 28: 161-174.

Galli C.I., Ramírez A., Reynolds J., Viramonte J., Idleman B. and Barrientos, C. 2011b. Procedencia de los depósitos del Grupo Payogastilla, provincia de Salta. Revista de la Asociación Geológica Argentina 68: 263 - 278.

Gasparini, Z. 1973. [Revisión de los Crocodilia (Reptilia) fósiles del Territorio Argentino: su evolución, sus relaciones filogenéticas, su clasificación y sus implicancias estratigráficas. Ph.D. dissertation Universidad Nacional de La Plata. Buenos Aires, Argentina, 169 p. Unpublished].

Gasparini, Z. 1981. Los Crocodylia fósiles de la Argentina. Ameghiniana 18: 177-205

Gatesy, J., Amato, G., Norell, M.; Desalle, R. and Hayashi, C. 2003. Combined support for wholesale taxic atavism in gavialine crocodylians. Systematic Biology 52: 403-422.

Gmelin, J. 1789. Linnei Systema Naturae. G.E. Beer, Leipzig, 1057 p.

Herbst, R., Anzótegui, L.M. and Jalfin, G. 1987. Estratigrafía, paleoambientes y dos especies de Salvinia Adanson (Filicopsida) del Mioceno Superior de Salta, Argentina. Revista de la Facultad de Ciencias Exactas y Naturales y Agrimensura 7: 15-42.

Herbst, R., Anzótegui, L.M., Esteban, G., Mautino, L.R., Morton, S. and Nassif, N. 2000. Síntesis paleontológica del Mioceno de los valles Calchaquíes, noroeste argentino. In: F. Aceńolaza and R. Herbst (Eds.), El Neógeno de Argentina. INSUGEO, Serie Correlación Geológica 14: 263288 .

Hrbek, T., Vasconcelos, W.R., Rebelo, G. and Farias, I.P. 2007. Phylogenetic relationships of South American alligatorids and the Caiman of Medeira River. Journal of Experimental Zoology 309: 588-599.

Hoorn, C., Wesselingh, F.P., Steege, H., Bermudez, M.A, Mora, A., Sevink, J., Sanmartín I., Sanchez-Meseguer, A., Anderson, C.L., Figueiredo, J.P., Jaramillo, C., Riff, D., Negri, F.R., Hooghiemstra, H., Lundberg, J., Stadler, T., Särkinen, T. and Antonelli, A. 2010. Amazonia Through
Time: Andean Uplift, Climate Change, Landscape Evolution, and Biodiversity. Science 330: 927-931.

Langston, W. 1965. Fossil crocodilians from Colombia and the Cenozoic history of the Crocodilia in South America. University of California Publications in Geological Sciences 52: 1-152.

Langston, W. and Gasparini, Z. 1997. Crocodilians, Gryphosuchus, and the South Americans gavials. In: R.F. Kay, R.H. Madden, R.L. Ciffelli and J.J. Flynn (Eds.), Vertebrate Paleontology in the Neotropics: The Miocene fauna of La Venta, Colombia. Smithsonian Institution, Washington D.C., p. 113-154.

Larriera, A. and Imhof, A. 2000. Proyecto yacaré, Santa Fe, Argentina: a sustentable use proposal. Proceedings of the 15th Working Meeting of the Crocodile Specialist Group, IUCN - The World Conservation Union, Gland, Switzerland and Cambridge, (United Kingdom), p. 311-313.

Linnaeus, C. 1758. Systema Naturae per regna trio naturae, secundum classes, ordines, genera, species, cum characteribus, differentiis, synonymis, locis. Tomus I. Laurentii Salvii, Stockholm, 824 p.

Lutz, A.I. and Martinez, L.C.A. 2007. Nuevo género y especie de liana del Mioceno Superior (Formación Palo Pintado), provincia de Salta, Argentina: Ameghiniana 44: 205-213.

Mauri, E. 1948. Observaciones geológicas en el sudoeste de la Provincia de Salta, departamentos Cafayate, San Carlos, Molinos, Guachipas y La Viña, Y.P.F. Unpublished internal report. Buenos Aires, 87 p.

Mautino, L.R. 2007. Chlorophyta de los Valles Calchaquíes (Mioceno Medio y Superior), Argentina. Revista Española de Micropaleontología 39: 81-102.

Medina, C.J. 1976. Crocodilians from the Late Tertiary of northwestern Venezuela Melanosuchus fischeri sp. nov. Breviora 438: 1-4.

Miall, A.D. 1985. Architectural-element analisis: a new method of facies analysis applied to fluvial deposits. Earth Science Research Journal 22: 261-308.

Miall, A.D. 1994. Reconstructing fluvial macroform architecture from twodimensional outcrops: examples from the Castlegate Sandstone, Book Cliffs, UTA. Journal of Sedimentary Research B64:146-158.

Miall, A.D. 1995. Description and interpretation of fluvial deposits: a critical perspective: discussion. Sedimentology 42: 379-384.

Miall, A.D. 2006. The geology of fluvial deposits. Sedimentary facies, basin analysis and petroleum geology. Berlin, London, Springer, $581 \mathrm{p}$.

Morton, L.S. 1992. Bivalvos de agua dulce de la Formación Palo Pintado (Mioceno Tardío) del Valle Calchaquí, provincia de Salta, Argentina: Revista de la Facultad de Ciencias Exactas y Naturales y Agrimensura 9: 77-91.

Norell, M.A. 1988. [Cladistic approaches to paleobiology as applied to the phylogeny of alligatorids. Ph.D. dissertation, Yale University, New Haven, Connecticut, 279 p. Unpublished].

Norell, M.A., Clark, J.M. and Hutchinson, J.H. 1994. The Late Cretaceous Alligatoroid Brachychampsa montana (Crocodylia): new material and putative relationships. American Museum Novitates 3116: 1-26.

Patterson, B. 1936. Caiman latirostris from the Pleistocene of Argentina, and asummary of South American Cenozoic Crocodilia. Herpetologica 1: 4354.

Piña, C.I., Larriera, A. and Siroski, P. 2004. Cocodrilos en la Región Litoral: especies, 631 distribución geográfica, modo de vida. In: F.G. Aceñolaza (Coordinador), Temas de la Biodiversidad del Litoral fluvial argentino. Revista del Instituto Superior de Correlación Geológica, Tucumán, Miscelánea 12: 317-322.

Poe, S. 1997. Data set incongruence and the phylogeny of crocodilians. Systematic Biology 45: 393-414

Price, L.I. 1964. Sobre o cranio de um grande crocodilideo extinto do Alto Rio Jurua, Estado do Acre. Anais da Academia Brasileira de Ciências 36: 5966.

Riff, D., Romano, P.S.R., Oliveira, G.R. and Aguilera, O.A. 2010. Neogene crocodile and turtle fauna in northern South America. En: C. Hoorn and E.P. Wesselingh (Eds.), Amazonia, Landscape and Species Evolution: A Look into the Past, $1^{\text {st }}$ ed. Blackwell Publishing, Oxford, p. 259-280.

Rovereto, C. 1912. Los cocodrilos fósiles en las capas del Paraná. Anales del Museo Nacional de Historia Natural de Buenos Aires 22: 339-368.

Rueda-Almonacid, J.V., Carr, J.L., Mittermeister, R.A., Rodríguez Mahecha, J.V., Mast, R.B., Vogt, R.C., Rhodin, A.G.J., Ossa Velásquez, J., De La, Rueda, J.N. and Mittermeister, C.G. 2007. Las tortugas y los cocodrilia- 
nos de los países andinos del trópico. Serie de guías tropicales de campo No 6, Conservación Internacional, Editorial Panamericana, Colombia, 538 p.

Rusconi, C. 1933. Observaciones críticas sobre reptiles Terciarios de Paraná (Familia Alligatoridae). Revista de la Universidad Nacional de Córdoba 20: $1-52$.

Rusconi, C. 1935. Observaciones sobre los gaviales fósiles Argentinos. Annales de la Sociedad de Ciencias Argentina 119: 203-214.

Sánchez-Villagra, M. and Aguilera, O. 2006. Neogene vertebrates from Urumaco, Falcon State, Venezuela: diversity and significance. Journal of Systematic Palaeontology 4: 213-220.

Scalabrini, P. 1887. Cartas Científicas. Museo Provincial de Entre Ríos.

Starck, D. and Anzótegui, L.M. 2001. The late Miocene climatic changePersistence of a climatic signal through the orogenic stratigraphic record in northwestern Argentina. Journal of South American Earth Sciences 14: 763-774.

Starck, D. and Vergani, G. 1996. Desarrollo tecto-sedimentario del Cenozoico en el sur de la provincia de Salta - Argentina. 13 er Congreso Geológico Argentino, Actas: 433-452.

Spix, J.B. 1825. Animalia nova sive Species novae lacertarum quas in itinere per Brasiliam annis MDCCCXVII-MDCCCXX jussu et auspiciis Maximiliani Josephi I. Bavariae Regis suscepto collegit et descripsit Dr. J.B. de Spix. T.O. Weigel, Leipzig 26 p.
Willis, R.E. 2009. Transthyretin gene (TTR) intron 1 elucidates crocodylian phylogenetic relationships. Molecular Phylogenetics and Evolution 54: 1049-1054.

Willis, R.E., McAliley, L.R., Neeley, E.D. and Densmore, L.D. 2007. Evidence for placing the false gharial (Tomistoma schlegelii) into the Family Gavialidae: inferences from nuclear gene sequences. Molecular Phylogenetics and Evolution 43: 787-794.

doi: 10.5710/AMEGH.11.12.2013.1507

Recibido: 29 de agosto de 2013

Aceptado: 11 de diciembre de 2013 